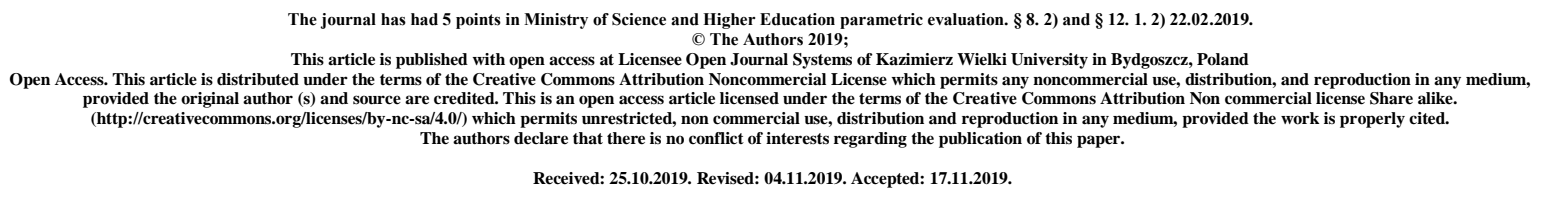

\title{
Models of digitisation of organisational space in sport
}

\author{
Wojciech Cieśliński, Paweł Piepiora*, Kazimierz Witkowski \\ University School of Physical Education in Wrocław
}

*Corresponding autor: Paweł Piepiora, University School of Physical Education in Wrocław, Faculty of Sport Sciences, Chair of Sport Didactics, I. J. Paderewskiego 35 street, Multifunctional Sports Hall room 73, 51-612 Wrocław, Poland, phone: +48 605395432 , e-mail: pawel.piepiora@awf.wroc.pl

\section{Summary}

This research presents the organisational model of digitisation of sport institutions as the element of development shifting towards digital models of sport business. Empirical research concerns: the level of saturation of information and communication technology (ICT) in sport institutions and media coverage of organizational space in sport as the element of media technology development. The research has been conducted in the theory of organisational space (Cieśliński, 2016, 2017) and has been financed with the use of two research-implementation grants and implementation one under the operational program Program Operacyjny Polska Cyfrowa (POPC).

Keywords: sport organisations, technological saturation, ICT, Augmented Reality (AR), expansion of organisational space, value chain, media coverage in sport.

The authors declare that the test procedures comply with ethical standards. There are no conflicts of interest between the authors. 


\section{Introduction $^{1}$}

The authors define digitisation as the transformation of real resources into digital ones. In the first part the authors present the findings of research, in the second they describe ontological and methodological application of advanced ICT technologies (Platforma e-AZS) and augmented reality (an educational trainer for sport) for stretching of value chains in sport space with reference to organization and education. The main findings of the research include:

- Firstly, the organisation functioning in two ontological spaces: real and virtual;

- Secondly, media space is the catalyst of change in the two aforementioned spaces;

- Thirdly, there is a possibility to expand organizational space with the use of technologies such as augmented reality, virtual reality and media;

- Fourthly, the extension of organisational space creates potential for value chain stretching;

- Fifthly, advanced technologies allow for extension of organisational space and stretching of value chain.

This research seeks to describe and explain the possibilities of creating new organizational reality which generates organizational potential of enterprises shifting towards stretching of value chain. Additionally, a new model of organizational space management has been developed based on the convergence of real, virtual and media processes.

The following aspects connected with the subject of study have been described below, namely: organisational space categorised with reference to types of organisational space, (real, virtual, media), issues connected with advanced information and media technologies, including augmented reality, augmented virtuality, augmented mediality. Finally, the model of organizational space extension was presented as the element of value chain stretching.

\section{Organisational space}

Organisational space can be simply defined as a nonempty set of relations and their interactions with objects and people.

Organisational space is created by organisational and inter-organisational networks of relations $^{2}$. Their nature can be tangible and intangible (by the authors viewed as virtual and media, whereas others view it as the network of people-to-people relations [Sztompka P. 2012, Nauka 4/2012 p.7-15, 2015].

Space is also the main epistemological-ontological category. According to Wittgentein (1998), it is the total number of relations between objects or sets containing them. Thus, space is a set of possible state of affairs. Organisational space can be defined as the state of affairs resulting from the relations between energy, information and physical fields of a given space. (Figure 1).

\footnotetext{
${ }^{1}$ the research is based on three research and implementation projects, two of them have been finished: 2013-2016, MNiSzW. Grant manager - Wojciech B. Cieśliński AWF Wrocław, grant no 0014/RS2/2013/52, titled; "Platforma e-AZS- wdrożenie mobilnego systemu zarządzania Klubem Sportowym AZS-AWF Wrocław" and between 2015-2017, grant manager Kierownik Kazimierz Witkowski, main contractor - Wojciech Cięśliński, grant MNiSzW no N RSA3 00153, titled: "Zaprojektowanie prototypu trenadżera judo z zastosowaniem technologii rozszerzonej rzeczywistości (augmented reality)" and currently being conducted project titled: "Aktywna Platforma Informacyjna e-scienceplus.pl"

no:POPC.02.03.01-00-0010/16 Grant Agreement no POPC.02.03.01-00-0010/16-00. Atlas Zasobów Otwartej Nauki (AZON). The project aims to digitise scientific resources of instututions of higher education: Technical University of Wrocław, Medical University and University of Life Sciences in Wrocław and Academy of Physical Education in Wrocław, where Wojciech Cieśliński is an expert coordinator.

2 Network of relations is described by: Czakon W. "Dynamika więzi międzyorganizacyjnych przedsiębiorstw", AE Katowice, 2007; Niemczyk J., Trzaska R. "Przywództwo i zarządzanie w sieciach międzyorganizacyjnych" [w:] Kaleta A. i Moskowicz K. (eds.) Zarządzanie strategiczne w praktyce i teorii, UE Wrocław, 2012, 260, 305-313; Stańczyk-Hugiert E., Gorgól J. "Elementy sieci międzyorganizacyjnych. Aspekty organizacyjno-zarządcze" [in:] Niemczyk J., Stańczyk - Hugiert E., Jasiński B. (eds.) Sieci międzyorganizacyjne. Współczesne wyzwania dla teorii i praktyki zarządzania, Warszawa, C. H. Beck, 2012.
} 
Figure 1. Space as the field of significance (energy, information, physical)

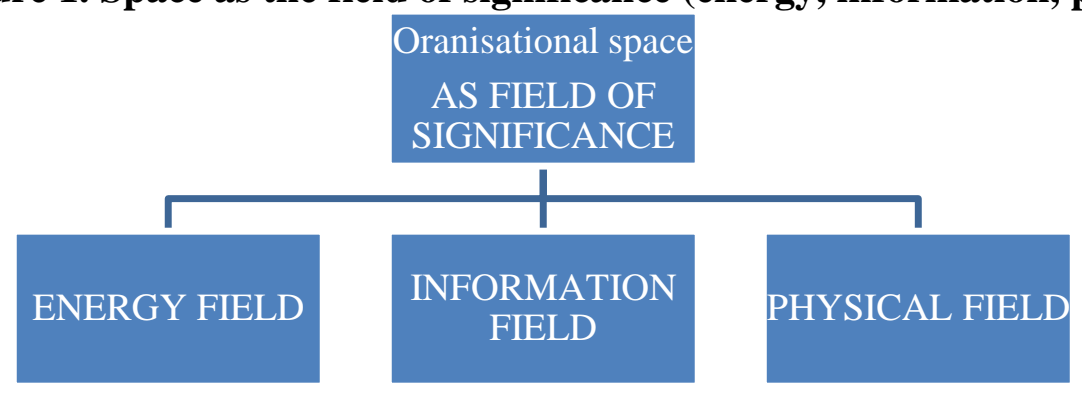

Source: own work

Organisational space can be described in terms of geography, mathematics and heuristics [Stępniak C., 2015. p.26]. Geographical space is characterized by real distance between objects, mathematical space is described as 2D (X,Y), 3D (X, Y, Z) and 4D described with the use of axis of time [op. cit. p.27]. Heuristic space is described as a semantic network explaining the relations between concept systems [op. cit. p.31] used in mapping of business processes [Cieśliński, 2011].

While describing organizational space, it is essential to indicate that it can be based on real, virtual and media relations. Each of these is resulting from events which occurred and/or were generated as well as their permutations, thus processes. Organisational space is therefore created on the basis of fields of significance with the use of events of energetic, informative or physical nature which create business processes as permutation.

Figure 2. Types of organisational space

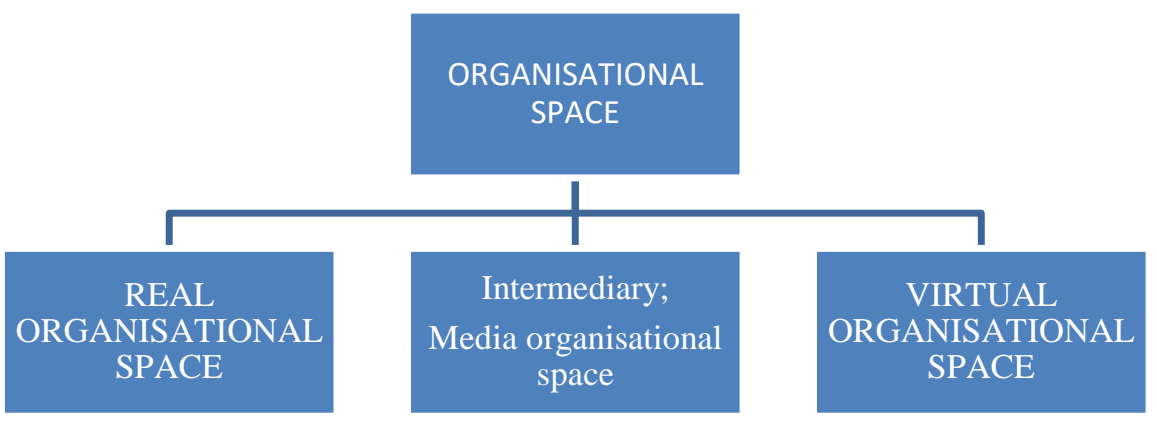

Source: own work

It is assumed that the integration of organisational space (real, virtual, media) and convergence of processes and events occurring in the space will contribute to developing the concept and organisational models which will in turn allow for stretching of value chain.

\section{Organisational space extension}

Figure 3 below presents the integration of three sectors of economy model by the means of mobile ICT systems. It points out that the integration of three sectors is necessary in projects concerning so called intelligent growth or smart specialisations. Such projects entail among others creating consortium whose participants include public bodies (e.g. universities) and/or non-governmental sector (e.g. foundations, associations, other). 
Figure 3. Integration of three sectors of economy model using the ICT - example of organisational space in sport

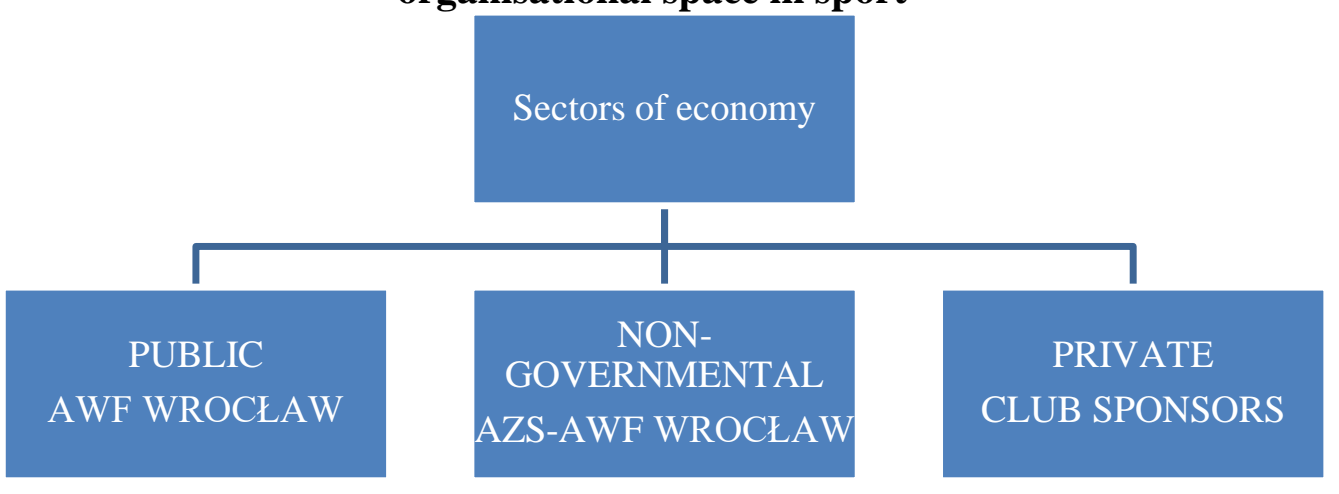

Source: own work

Alternatively, the extension of organisational space, thereby value chain stretching, is possible with the use of idea and technology of augmented reality. Thus, the extension of reality with the use of modern IT technologies enables to stretch value chain through generating future events. A new paradigm points out there is another view on this issue.

Figure 4. Ontological structure of organisational space expansion

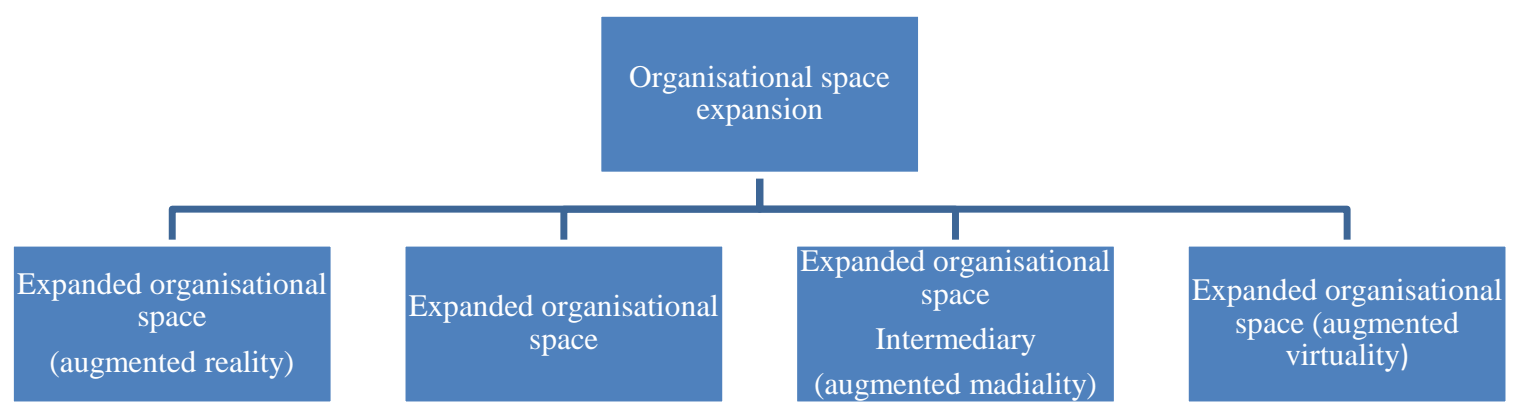

Source: own work

The research resulted in development of advanced model of organisational space boundaries mechanism, which facilitates 'stretching' of real (tangible), virtual (intangible) and media value chain. It has been proven that pushing the boundaries of organisational space leads to stretching of value chain, i.e. creation of new values using mobile ICT systems and Augmented Reality. The extension of organizational space is thus the first step in generating new values and competing.

Organisational space extension and value chain stretching - empirical research findings on saturation of ICT technology and media coverage in sport

Nowadays, the value chain stretching is done through the use of convergence of real, virtual, media processes mechanism by the means of mobile ICT systems, at the same time integrating three sectors of economy while realizing projects of intelligent growth, in which we deal with three types of values. These values include tangible, intangible and media ones (figure 5). The last more and more often constitute an important aspect of running a company [Cieśliński, Kopecka-Piech, Głowicki, Perechuda, Pawlukiewicz, 2015, p. 254-262]. 
Figure 5. Value chain structure

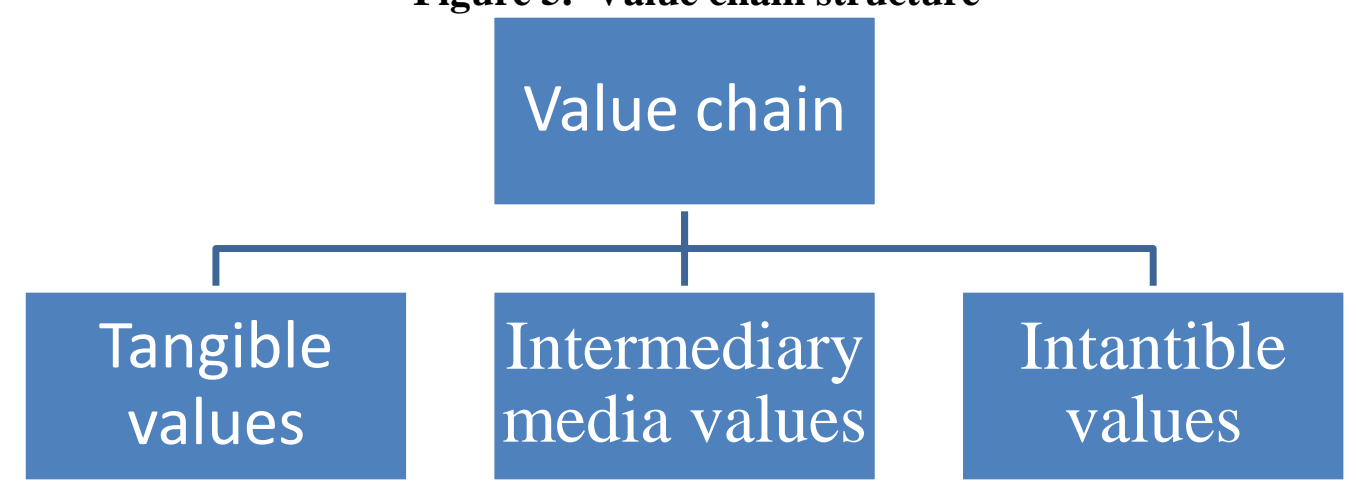

Source: own work

The above assumptions allow for initial designing of mix reality model, where one can point out the matrix between organisational space of public, private and non-governmental domains, as well as organisational space: real, virtual and media. We deal with real, virtual or media reality in organisational space when particular events in spaces do not enter in relations; when there is interaction, we deal with extended reality. The above mentioned assumptions were used to describe the ways of applying mechanisms of organisational space extension in value chain stretching. The table 1 presents matrix mix reality based on augmented reality. As it can be observed there are three mechanism of value chain extension (real, virtual and media). On the other hand, advanced technologies like augmented reality, virtuality and mediality allow to stretch tangible, intangible and media value chains. Research on the saturation of real, media and virtual spaces in sport business proved unambiguously that the saturation of these areas with IT technology has great importance in the context of obtaining augmented reality mix. In order to realise the study's purpose, the authors conducted a survey with 120 respondents $^{3}$ and made a conclusion that the motivation connected with saturation of space with IT technologies in the test sample is driven by the need to reduce work time and costs or improve the functioning of organization. Extended value connected with saturation of work environment with IT technologies remained a second choice.

The research proved that IT technologies, according to respondents, affect the efficiency and quality of sport organisation management, which resulted in generating big amounts of data aggregated in the form of data bases, including detailed information on functioning of organisation and its members. Indicating IT tools as those used in internal communication and helping in information flow was an essential element of augmented mix reality. Some of the elements indicated as those connected with IT saturation in sport enterprises were the possibility to send data, use application for training and verification of score. Nearly $60 \%$ of respondents remarked on the possibility of social media $(58.3 \%)$ impacting target groups or internal clients. The positive reception of IT tools usability was reflected in the findings concerning sport enterprises' usage of IT (96.7\% supporters) and general evaluation of such investment profitability, which according to respondents was at the level of $93 \%$.

The research findings reflect on one more essential piece of information in the context of saturation of organisational space with IT, namely, that IT impact is noticeable for $92 \%$ surveyed, who later indicated that in the next years IT is going to play more important role in sport organisations $(99.1 \%)$. Later research, based on the defragmentation of sport organisation, sectioned those fragments of space that gain most in the process of saturation

\footnotetext{
${ }^{3}$ The analysis was conducted for the group of sport organisation employees holding expert positions, where women constituted $61.7 \%$ and men $38.3 \%$, randomly chosen.
} 
with IT. The biggest beneficiaries, according to respondents, are processes connected with communication (80\%), advertising (68.30\%), market research $(60 \%)$ and logistics $(59.20 \%)$.

Given the results of research it can be concluded that IT has particular influence on given areas of sport organisation, stretching value chains at the same time. The largest IT saturation takes place in the sphere connected advertising activities and direct support in communication. The saturation of sport organization space with IT has impact on value chains stretching. The provided research allows for estimation of future IT saturation. According to the study, the bigger the saturation of organizational space of sport enterprises is, the better contact with contestants and clients is, along with faster flow of information and possibility to verify contestants' score based on huge volumes of data in protected virtual, easily accessible space.

\section{Extension of value chain with the use of social media}

The other element constitutes the correlation of mediatisation with real financial value of contestants. The research presents in detail media value of contestants and its correlation with the value of their contracts due to mediatisation. It was proven that media space is the place of generating material values such as contracts or salaries. These material values increase as the result of conversion process of real space into virtual and then media ones. Reconversion generates the whole array of material values for players, sport clubs, institutions organising gameplays and spectators. Thus, the research on the influence of extension of organisational space of sport institutions with the use of IT beyond real and media space provides the answer to the question: how to gain value synergy from the saturation.

Convergence of value chains in real, virtual and media organisational spaces of enterprises blurs these values, since each value is generated in a different dimension of organisational space and by other medium. Saturation of sport space with IT holds its special place in the area of social media. Media create public forum and allow people who do not know each other to discuss topics chosen and subscribed to by them. The topics could be related to a phenomenon, figure, subject or organisation. The research on salaries of key contestants of sport organisations pointed out that their sport skills may not always reflect measurable economic and media value. Thanks to extension of reality with the use of IT tools and solutions, following popular sport idols gains new space, and at the same time it has become independent of time, which is not related to a certain competition taking place during a particular sport event.

Interestingly, using social media in communication with fans creates the possibility of interaction between the sport idol and his fans, hence, enables the view exchange and fans involvement. Daily reports produced with the use of Facebook, Twitter or YouTube translate into the value of contracts concluded with a given sportsperson. Pending the research, it has been observed that there is a correlation between a big number of fans and contract value of given players. This correlation is shown between the salaries of 10 top earning players of American league and the number of all followers in social media. There are basically no players with low popularity in social media who would earn top salaries. Their popularity correlates strongly with their remuneration. The reason for this is the fact that social media help promote sport results, thus player's own image in the network including other, sometimes controversial activities like scandals. What is more, sponsors tend to co-operate with players who have bigger number of fans in social media (which directly translates into the level of their salaries). 
Table 1. Model of organisational space expansion mechanism and value chain stretching with the use of augmented reality

\begin{tabular}{|c|c|c|c|}
\hline $\begin{array}{c}\text { Events and processes } \\
\text { / mechanisms of } \\
\text { organisational space } \\
\text { extension }\end{array}$ & $\begin{array}{c}\text { Real events and } \\
\text { processes }\end{array}$ & $\begin{array}{c}\text { Virtual events and } \\
\text { processes }\end{array}$ & $\begin{array}{c}\text { Media events and } \\
\text { processes }\end{array}$ \\
\hline 1 real mechanism & $\begin{array}{c}\text { Stretching of tangible } \\
\text { value chains }\end{array}$ & $\begin{array}{c}\text { Stretching of virtual } \\
\text { value chains }\end{array}$ & $\begin{array}{c}\text { Stretching of media } \\
\text { value chains }\end{array}$ \\
\hline 2 virtual mechanism & Augmented reality & Augmented virtuality & $\begin{array}{c}\text { Augmented } \\
\text { mediality }\end{array}$ \\
\hline 3 media mechanism & $\begin{array}{c}\text { Stretching of media } \\
\text { value chains } \\
\text { (traditional, } \\
\text { industrial media) }\end{array}$ & $\begin{array}{c}\text { Stretching of } \\
\text { intangible value } \\
\text { chains with the use } \\
\text { of new media }\end{array}$ & $\begin{array}{c}\text { Stretching of } \\
\text { intangible value } \\
\text { chains in media } \\
\text { space }\end{array}$ \\
\hline
\end{tabular}

Source; own work

\section{Augmented reality and ICT as tools for stretching value chains}

On the one hand, organisational space is created with the use of ICT, characterised by ICT networks in organisational space. On the other hand, it is possible to expand (stretch) this space through superimposing real images onto virtual ones. Additionally, it is pointed out that this continuum must be complemented by media events (what is characteristic of contemporary organisation is the fact that business grows using media facts created in real space (industrial media) and social space (social media - new media)).

One of the elements of organisational space extension is media space. Industrial media (traditional ones) generate real media facts. While using social media, media space extension takes place (augmented mediality), which can generate media facts creating other than real media facts. A value chain is defined by the sequence of events (permutation), activities or processes that allow for providing and/or selling a client (including internal one) a product or service which he/she will be willing to pay for. The value chain stretching aims to identify new and modify old products or services

Real organisational space generates real events. A real event using augmented reality (AR) can create future events and be the element of value chain stretching by virtual elements (computer generated) or media (generated in media space). In virtual reality the computer generates events and allows for value chain stretching with the use augmented virtuality (AV). The computer generated event is later superimposed by the event from real and media space. In media space, with the use of augmented mediality (AM), the media events (similarly to industrial media and social media) are superimposed by real and virtual ones

Augmented reality is treated as the way to improve mediality of television broadcast, starting from real time broadcasting of a football match, which could be ideal, and continuing with showing the difference between the world record and actual series, e.g. swimming, sky jumping or athletics.

\section{Summary - models of value chain stretching as the process of generating future events}

Extension of organisational space with the use of social media (augmented mediality $A M)$, means moving the tasks creating organisational added value from industrial media space to social media. Contemporary organizations smoothly move from real to virtual space. The intermediary variable taking part in the process of organisational space extension is media space. The processes which create the value take place at the border of real and virtual space. The carrier of this value is social media which could be called augmented mediality AM, analogically to AR and AV technologies. 
Therefore, extension of organizational space with the use of AR, AM and AV plays crucial role in value chain stretching.

Ultimately, one can define the following models of future events (value chain stretching):

1. Model of value chain stretching with the use of AR.

2. Model of value chain stretching with the use of AM.

3. Model of value chain stretching with the use of AV.

The essential element in value chain stretching constitutes integration and cooperation of entities in three sectors of economy. The example of value chain stretching through the integration of the three sectors is the program NCBiR 'Innowacje społeczne', where the consortium must consist of public, non-governmental and private entities.

The above assumptions represent developmental trends of organisational (theoretical and practical), managerial boundaries and the concept of virtual organisation boundaries. There is huge technological advancement observed, regardless of the presented data. Development trends describe phenomena that have been used operationally until now (Chomiak-Orsa, Cieśliński, 2015]. Real, virtual and media spaces overlap with one another. It is essential to find the ways of their convergence to better and more effectively act in real space. Future events generated with the use of AR, AV or AM will probably become more tangible elements than traditional precognitive forms, which often do not appear in information aspect and are difficult to define with scientific instruments, as the energy field is involved. The studies in the field of cognitive science dealing with convergence of processes of real, information and energy fields will probably be conducted in the future.

\section{References:}

1. Chomiak-Orsa I., Cieśliński W. (2014) Business Informatics, UE Wrocław, 4 (34).

2. Cieśliński W. (2011) Doskonalenie procesowej orientacji przedsiębiorstw. Model platformy treningu procesowego. UE Wrocław.

3. Cieśliński W., Witkowski K., Migasiewicz J., Perechuda I., Rokita A., Chomiak-Orsa I. (2014) e-AZS Platform model - the koncept of application of information and communications technology in sport enterprises [in:] Chomiak-Orsa I., Cieśliński W. (eds.) Business Informatics, UE Wrocław, 4 (34).

4. Cieśliński W., Kopecka-Piech K., Głowicki P., Perechuda I., Pawlukiewicz A. (2015) Teoretyczne i praktyczne aspekty zarzadzanie granicami przestrzeni organizacyjnej a kreowanie wartości medialnej [in] Kiełtyka L., Jędrzejczyk W. (eds.)Wykorzystanie potencjatu współczesnych technologii informacyjnych $w$ zarządzania organizacjami, Politechnika Częstochowska, 297.

5. Cieśliński W. (2015) Space organization [in:] Perechuda K. (ed.) Advased Business Model, UE, Wrocław.

6. Perechuda K. (1999) Metody zarządzania przedsiębiorstwem, AE Wrocław.

7. Selhorst T. (2007) New Method for Medical Augmeneted Realty (Desirtaion), Technische Universitet in Mencheim in Medizine.

8. Stępniak C. (2015) Przestrzeń jako zasób w pobudzaniu przedsiębiorczości [in:] Jelonek D., Turek T. (eds.) Kreowanie przedsiębiorczości. Perspektywa procesów $i$ technologii informatycznych, Częstochowa.

9. Witgestein L. (1998) Niebieski $i$ brazowy zeszyt. Szkice do "Dociekań filozoficznych"(The Blue and Brown Books. Preliminary Studies for the "Philosophical Investigations"), Spacja, Warszawa. 
Additional sources:

Acquia, Customers Want Personalized Content and Data-Driven Commerce [online], in: acquia.com [access: 7.10.2017], <https://www. acquia.com/de/blog/customers-wantpersonalized-content-and-data-driven-commerce $>$.

Barycki P., Jak daleko nam do autonomicznych samochodów [online], in: Spider's Web [access: 7.10.2017], <http://www.spidersweb. pl/2016/10/autonomiczne-samochodykiedy.html>.

Boyle M., Aging Boomers Stump Marketers Eyeing \$15 Trillion Prize [online], in: „Bloomberg” [access: 7.10.2017], <https://www. bloomberg.com/news/articles/2013-0917/aging-boomers-befuddle-marketers-eying-15-trillion-prize $>$.

Caylar P.-L., Naik K., Noterdaeme O., Digital in industry: From buzzword to value creation [online], in: Digital McKinsey [access: 7.10.2017], <https://www.mckinsey.com/businessfunctions/digital-mckinsey/our-insights/digital-in-industry-from-buzzword-to-valuecreation>.

Desai P., Potia A., Salsberg B., Retail 4.0: The Future of Retail Grocery in a Digital World [online], in: sipotra.it [access: 7.10.2017], <http:// www.sipotra.it/wpcontent/uploads/2017/06/The-future-of-retail-grocery-in-a-digital-world.pdf>.

Desjardins J., What happens in an internet minute in 2017? [online], in: World Economic Forum [access: 7.10.2017], <www.weforum.org/ agenda/2017/08/what-happens-in-aninternet-minute-in-2017>.

Digital/McKinsey, Cyfrowi Polacy. Konsumenci w czasach e-rewolucji [online], in: mckinsey.pl [access: 7.10.2017], <http://mckinsey.pl/ wp-content/uploads/2016/09/RaportCyfrowi-Polacy.pdf>.

Elbil, Norwegian EV market [online], in: elbil.no [access: 7.10.2017], <www.elbil.no/english/norwegian-ev-market>.

Gemius, E-commerce w Polsce 2016. Gemius dla e-Commerce Polska [online], in: ecommercepolska.pl [access: 7.10.2017], <https://ecommercepolska.pl/files/9414/6718/9485/E-commerce_w_polsce_2016.pdf>. Germany Trade \& Invest, Electromobility in Germany: Vision 2020 and Beyond [online], in: gtai.de [access: 7.10.2017],

<https://www.gtai.de/GTAI/Content/EN/Invest/_SharedDocs/Downloads/GTAI/Brochures/In dustries/electromobility-in-germany-vision-2020-and- beyond-en.pdf?v=3>.

Giffinger R. i in., Smart Cities. Ranking of European medium-sized cities [online], in: smartcities.eu [access: 7.10.2017], <http://www. smart-

cities.eu/download/smart_cities_final_report.pdf $>$.

Hermann M., Pentek T., Otto B., Design Principles for Industrie 4.0 Scenarios: A Literature Review [online], in: Technische Universitat Dortmund 2015 [access: 7.10.2017], $<$ http://www.snom.mb.tu-dortmund.de/cms/de/forschung/Arbeitsberichte/Design-Principlesfor- Industrie-4_0-Scenarios.pdf>.

Kharas H., The unprecedented expansion of global middle class. An update [online], in: brookings.edu [access: 7.10.2017], <https://www. brookings.edu/wpcontent/uploads/2017/02/global_20170228_global-middle-class.pdf >.

Kondratowicz A.C. [online], in: Towarzystwo Ekonomistów Polskich [access: 7.10.2017], <https://drive.google.com/file/

d/0B6z6Svs4V1C9MkQza09jcHpQMEU/view?ct=t(NEWSLETTER_1_20173_14_2017)>. Łopusiewicz A., Uber ma sporo do zrobienia. Poznajcie jego 10 największych rywali [online], in: mamstartup.pl [access: 7.10.2017], <http:// mamstartup.pl/sukces/10135/uberma-sporo-do-zrobienia-poznajcie-jego-10-najwiekszych-rywali> 